\title{
Efficacy of Balanced Scorecard on Performance of Banks in Nigeria
}

\author{
Michael P. Nnamseh, Ph. ${ }^{1 *}$ \\ Victor A. Umoh, Ph. $\mathrm{D}^{1,2}$ \\ Department of Business Management, University of Uyo, Uyo, Akwa Ibom State, Nigeria
}

\begin{abstract}
This study examines the efficacy of balance scorecard (BSC) on the performance of banks in Nigeria as one of the most topical issues in the banking sector. The study was motivated by the imperfections of traditional performance measurement system which is inadequate as it is limited to financial analysis and does not provide for an integrated analysis of performance that captures the non-financial variables, such as customer, learning and growth and internal business process. The study was based on expost facto research design and made use of historical data of five selected banks spanning a period of eleven years (2007-2017). It was hypothesized that customer internal business process, learning and growth and financial perspectives have no significant effect on the performance of banks in Nigeria. The result indicates that customer perspective and internal business process perspective have significant effect on performance of banks in Nigeria, while financial perspective and learning and growth perspective have no significant effect on banks performance in Nigeria. It was recommended that banks in Nigeria should adopt the BSC approach to measure and manage their performance in view of its capacity to provide a comprehensive information on bank performance evaluation. It was further suggested that banks should be more innovative on customer and internal business process aspect of their operations in order to maximize performance. It is also stressed that banks should accord learning and growth components of their operations a significant attention.
\end{abstract}

Keywords: Balanced Scorecard, Bank Performance and Measurement, Nigeria

DOI: $10.7176 / \mathrm{EJBM} / 11-23-05$

Publication date: August $31^{\text {st }} 2019$

\subsection{Introduction}

Organizations are operating in a very competitive environment. To develop and sustain competitive advantage, business organizations must determine their performance measurement system. In doing this, the organization is in a position to assess the direction the business is going. In specific terms, performance measurement is targeted at improving performance of an organization so that it may serve its customers, employees, owners, stakeholders and host community in a more dignified and qualitative manner. A performance measurement system enables an organization to plan, measure and control its performance according to predefined strategy (Okwo and Marire, 2012). It is generally defined as regular measurement of outcomes and results, which generates reliable data on the effectiveness and efficiency of programmes and strategy (Collins and Greg, 2016).

In the past few decades, not until a recent change in business philosophy, most organizations' main objective had been to maximize profit, even without satisfying the customers and its critical stakeholders interest. Consequent upon this misplaced motive, organizations relied solely on the organizations' financial returns to draw conclusion on how well the organization is dong within the period of evaluating. While the financial performance of a business is a major component of a business performance indicator and highly desirable, it is grossly insufficient and partly misleading for executing decision making owing to its inherent limitations. Singh and Kumar (2007), criticised the financial performance measure for being short-term oriented, focusing on tangible assets alone, lacking predictive power, reinforcing functional silos and being irrelevant for some levels in the organizational hierarchy. Given credence to this position, Malcom (2016) added that the approach is non-consistent with current business environment.

Kairu, Wafula, Okaka, Odera and Akerele (2013) observed that from inception, organizations usually set their objective and benchmark relative to customers' satisfaction rates, product defect rates, lead time to market and environmental/social responsibility and that these goals are not measured directly in financial terms. From this perspective, it is important therefore, that the non-financial performance measures should be developed to indicate a holistic standing of the organization toward achieving the predetermined strategy of the organization. Since the non-tangible performance measures contribute to the achievement of the overall corporate performance, it is only right and reasonable that they should be incorporated in the evaluation.

The gap created by the exclusion of the non-financial indicators and the criticism trailing the exclusive use of the financial performance measurement provoked researches which saw the emergence of the balance scorecard (BSC) as a more integrative and effective tool for corporate performance measurement. The BSC is a performance measurement tool that translates an organizations' strategy into clear objectives, measures, targets and initiatives organized into four perspectives: financial, customer, business process and human resources or innovation and 
learning (Kassahun, 2010).

According to Kaplan(2010), the major objectives of BSC is that as an organization exposes its employees to learning experience, it will automatically transcend to improvement in internal business process; and this will lead to improved customer satisfaction; which ultimately will culminate to improved financial earnings. From this context, BSC is not merely an instrument for measurement but it focuses more on the improvement of corporate performance through periodic evaluation. The application of BSC allows managers to assess how their organization create value for current and future customers, how internal processes can be improved, how human development can be enhanced and other salient approaches to better future performance.

Given the crucial role of the banking sector in Nigeria as the hub of national development, the study objective is to investigate the implications of BSC on the performance of banks in Nigeria. Its specific aims includes: (i) examine the effect of financial perspectives on business performance of banks in Nigeria (ii) investigate the effect of customer perspective on banks performance in Nigeria (iii) assess the effect of internal business process perspective on banks performance in Nigeria and (iv) investigate the effect of learning and growth perspective on bank performance in Nigeria. To achieve these objectives it was hypothesised that: (i) financial perspective has no significant effect on the performance of banks in Nigeria (ii) customer perspective has no significant effect on the performance of banks in Nigeria (iii) internal business process has no significant effect on the performance of banks in Nigeria and (iv) learning and growth perspective has no effect on the performance of banks in Nigeria. The study is premised on the fact that the use of financial performance measurement alone denies corporate organizations of a realistic and an all inclusive indices of evaluation of an organizations' progress report.

\subsection{Theoretical Framework and Conceptual Issues}

Many theories have emerged in support of BSC approach. The most prominent and relevant theory that gives credence to this study is the stakeholder theory. According to Abram (1951), stakeholder theory situates on issues concerning stakeholders in an organization. It stipulates that an organization desire to provide a balance between the interest of its numerous stakeholders in order to ensure that each interest constituency receives some degree of satisfaction. The theory attempt to justifying why organizations make efforts at achieving competitive advantage that will enhance their sustainability. Stakeholders are interested in profitability of their investment as reported by Return on Asset (ROA) and Return on Equity (ROE). Customers are interested in their experience in areas such as prompt service delivery, empathy, convenience and etc. Employees have concerns in the aspect of welfare, training and development, job security and participatory management. Government and creditors are interested in the soundness, effectiveness and efficiency of organizations as represented by their internal business process perspective (Akpan, 2013, Mullin, 2014; Levit, 2016 and Edward, 2016). The theory argues for a holistic development and management of strategies along different stakeholder's dimensions in order to successfully manage and report performance in line with the different goals. An in-depth analysis of the theory further reveals that stakeholders' interest should be seen as the only cardinal objective of organizations.

\subsection{Balanced Scorecard (BSC)}

The BSC was developed as part of an attempt at improving the measurement of organizations' performance. This is because; relying solely on financial component of performance analysis has been seen as inadequate in presenting a true picture of organizational performance. Furthermore, this approach no longer provides realistic parameter for measuring modern businesses (Kaplan and Norton, 2001).

The BSC is considered to be capable of addressing issues confronting management such as unreliable performance measures coupled with the need to measure intangibles and integrate same with tangibles in order to improve the performance of organization (Kaplan and Norton, 2001). By inventing the BSC, the idea was for it to serve as a strategic management compass that guides businesses into translating their strategic goals into appropriate metrics for ease of evaluation (Kaplan and Norton, 2001). It is a system used by a firm to describe and manage its strategies. Using the BSC enables organization achieve strategy clarification, communication and linkage with long-term goals. It also provides the metrics to be used in planning, setting targets for the organization and also having feedback (Kaplan and Norton, 1996).

Kaplan and Norton (1992) believe that relying completely on financial performance metrics used to be suitable for organizations during industrialization era but that with current age where no knowledge and ability are commonplace, financial measures are no longer sufficient for use in determining organizational performance. Accordingly, excessive uses of financial metrics have been criticized because:

1. There has been a rise in the importance of non-financials which are seen as drivers for future performance. Measures used traditionally to assess do not take into account such variables as customer satisfaction, service quality, learning and growth opportunity, employees satisfaction and the like.

2. The traditional performance measures lack the predictive power to indicate the direction for future operations of the organization.

3. Financial performance cannot integrate cross -functional as well as team work operations when in actual fact 
what is presented as performance financially is a composite of different functional areas' contributions.

4. Financial performance appears short -term in orientation as against issues that engender long-term success ; this short-term approach may threaten strategic success.

5. The focus of financial metric which is short -term financial success fail to involve all levels of the firm as it only summarize organizational performance which may not be in useable form for employees' daily use.

The balanced scorecard has four perspectives that organizations are expected to pay attention to: customer, internal business process, financial; and learning and growth perspectives. This depicted in the conceptual model below.

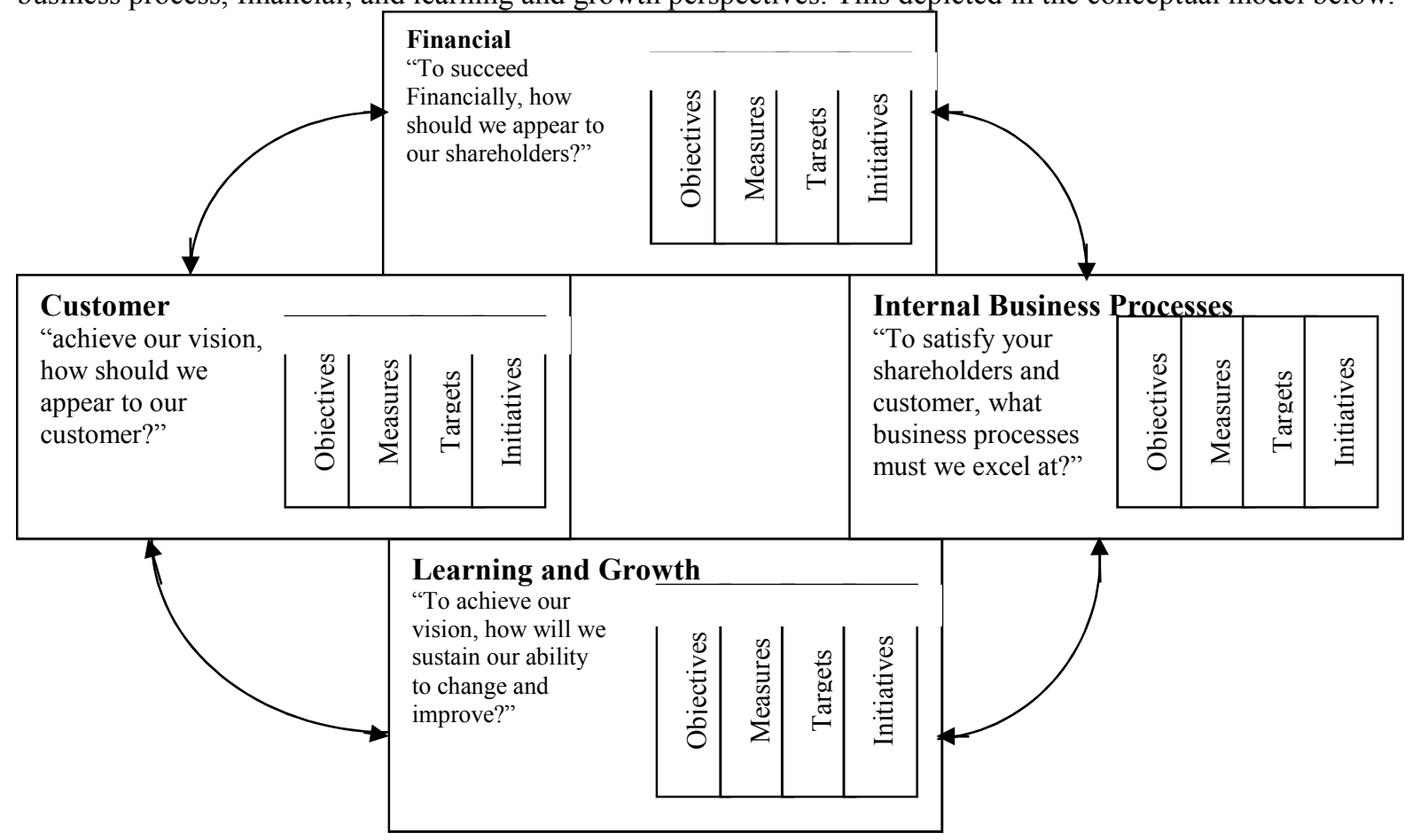

Figure 1: BSC Perspectives

Source: Kaplan and Norton (1996)

Figure 1 presents BSC perspectives, details on each of the perspectives are given below:

1. The Financial Perspective: This perspective enables an organization conduct an assessment of its strategies and how they are being translated into profit for the business. Goals that are financial in nature include: return on investment, profitability, growth in revenue, return on asset, stakeholders' value (Kaplan and Norton, 1992). While financial indicators are considered indispensable for assessing business performance, their main shortcoming is that they reflect the results of managerial decisions made previously and do not indicate what the organization is doing presenting towards improving its performance in future.

The financial perspective considers metrics representing the ultimate long-term goal of the firm. Every organization targets giving returns which meet and exceed the expectations of shareholders. The BSC does not contradict this goal but stresses the need to manage and address all issues capable of influencing the realization of financial goals. Using financial information which are historical is a major issue leading to criticism of traditional performance analysis as it does not provide sufficient data concerning future performance of the firm.

The Balanced Scorecard was conceived to tackle the limitation caused by excessive dependence on financial metric. Financial measures are still relevant and constitute an aspect of the BSC. According to Kaplan, metrics under the financial perspective should show how strategy implementation in a firm contributes to enhancing improved performance results.

2. The Customer Perspective: The customer perspective tracks customer related issues such as satisfaction, attitudes and market share goals. This perspective is aimed at ascertaining the needs of the customers which as reported by Kaplan and Norton (1992) include service, time, quality, performance and costs. Metrics in this dimension of performance are considered leading indicators of future performance. Zeithaml and Bitner (2003) see customer satisfaction as the customers' judgment of service enjoyed or product used as meeting their needs. When customers are satisfied they behave in a positive manner by repeat patronage for the business.

In this perspective, strategy targeted at creation of differentiation and value distinguished from the angle of the client is considered. The perspective creates a value proposition in the sense the customer sees and appreciates the product or service, its price, image and relationship as unique and differentiated from others. The value 
proposition may come from excellence in operations, leadership in product and deepened customer relationship (Kaplan and Norton, 2001). This perspective enables the firm to strategize on how to satisfy the expectations of clients in order to achieve its financial goals.

Kaplan and Norton (1996) advise that for the firm to meet and satisfy the expectations of its clients and so meet its own long-run financial goals, it has to deploy its services or products in meeting clients' expectations. The implication of this is that management should be able to translate organization's strategy and mission into appropriate clients' goals. Continued the authors listed customer perspective metrics as including customer retention, market share, client satisfaction, profitability of costumer and client acquisition. While customer retention relate to how the business manages client relationship to retain patronage, market share indicates proportion of the business controlled by the firm; profitability of the customer shows how the clients are supporting business profits per segment and customer satisfaction captures the feelings and opinions of clients as it concerns the service offered and products enjoyed. Satisfied clients repeat the patronage. Customer satisfaction in the Nigerian banking industry may not be different from above description.

3. The Internal Business Process Perspective: The concern of this perspective is the internal operational goals needed to meet customer objectives. It enables an organization to evaluate the performance and extent to which its offerings to the market are meeting customers' envisioned expectations. This perspective is concerned with measures such as service measures, quality measures, cost reductions, efficiency measures, lead times, innovation rates and the likes. The basic premise of the internal business process perspective is that it recognizes the importance of customer-based targets but stresses that they should be converted into such metrics that indicate those things that are being done by firms so as to realize expectations of clients (Kaplan and Norton, 1992).

The internal business process perspective showcases the priorities that are strategic concerning the processes the organization would have to do well in order to bring about the satisfaction of both shareholders and customers. This perspective indicates how the firm will be creating and delivering client value proposition as well as improvement in performance as represented by attainment of financial goals (Kaplan and Norton, 2001).

Atkinson, Kaplan, Matsumura and Young (2009) give a breakdown of the internal business process perspective of performance as including four classes.

i. Operational management process: This has to do with the daily activities and processes which lead to production and offering of goods and services to clients. The affected processes include those of improvement in utilizing assets, improvement in quality, costs and time, achievement of superior capabilities in supplies and responsive delivery of services and goods to clients.

ii. The process of managing customers: This is the aspect that supports customer relationship. It has the objective of signing on new clients to the business of the organization, satisfying and retaining current customers and generating growth with clients.

iii. Innovativeness: This aspect deals with new product or service development in order to have additional customer groups and new markets. Under innovativeness two sub- classes are those of:

i. Developing innovative services and products

ii. Achieving research and development excellence

iv. Processes that are social and regulatory- These concern standards set regarding staff, community interests, safety and health, ecological issues and employment issues. The reasoning is that as firms strive to meet and exceed these standards, they are invariably improving their image and goodwill which may result in attracting and retaining high performing employees, addressing ecological issues and patronage.

4. The Learning and Growth Perspective: This perspective is aimed at determining an organization's ability to continually improve and innovate. It examines how an organization learns and grows (Wong, Kuek and Ong, 2013). It focuses on intangible drivers of future success including human capital, employee capabilities, organizational capital, employee productivity, training, growth in number of employees, employee turnover, work force diversity, education and development, informational systems and the like.

This perspective of the BSC sets priorities required to engender at atmosphere which facilitate organizational change, growth and innovativeness. This is where the firm is concerned with defining resources, skills and atmosphere supportive of its strategies. This perspective creates a strategy map which provides a link across the four perspectives of the BSC. The important areas of the perspective are those of employee - their skills and competencies in strategy execution, the information technology (IT) that is required for process improvement; alignment of organization and culture. For Kaplan and Norton (1996), learning and growth perspective has three categories: Capabilities of employee, information system resources and motivating employees, aligning its activities and units.

Employee capabilities assess satisfaction of employees, their productivity and retention; it is employee satisfaction that results in staff productivity and their decision to stay put with the organization. Information system is equally needed for accurate and timely data for decision- making. This information may concern competitors and their moves, clients, technological development, government policies and the like. Appropriate 
motivation is also needed to get the best performance from employees under the learning and growth perspective; the firm has to strategize by initiating strategies that require it to do more in terms people investment, systems enhancement and process management.

\subsection{Methodology}

This study adopted Ex post facto research design. This design was considered appropriate as it involved using historical data covering 11-year period (2007-2017) to investigate the effect of independent variable, BSC (decomposed into customer, internal business process, learning and growth and financial perspectives) on dependent variable, banks' performance, proxied by ROE. This study's population was all the 22 licensed banks that operated in Nigeria as at December 2017.

In this study, five banks namely, First Bank of Nigeria Plc (FBN), United Bank for Africa (UBA), Access Bank Plc(AB), Zenith Bank Plc(ZB) and Guarantee Trust Bank Plc(GTB), respectively rated amongst the top 10 players in the Nigerian financial landscape were selected judgmentally for investigation. In view of the volume of business controlled by them, the sampled banks gave insights into the performance of banks in the country when evaluated with BSC. To ascertain the direction or nature of relationship and how significant the degree of effect of BSC on the bank performance, the study employed a multiple regression statistic/model shown below:

$\mathrm{Y}=\mathrm{a}+\beta 1 \mathrm{FP}+\beta 2 \mathrm{CP}+\beta 3 \mathrm{IBP}+\beta 4 \mathrm{LGP}+\mathrm{e}$

Where:

$\mathrm{Y}=$ Banks' Performance

$\mathrm{FP}=$ Financial Perspective

$\mathrm{CP}=$ Customer Perspective

IBP $=$ Internal Business Process Perspective

$\mathrm{LG}=$ Learning and Growth Perspective

$\mathrm{a}=\mathrm{Y}$ intercept

$\beta_{1} \beta_{2} \beta_{3} \beta 4=$ the regression coefficient of the four dependent variables

$\mathrm{e}=$ Error

Presentation and Analysis of Empirical Results

Test of Hypotheses

Table 1: Results of Multiple Regression Analysis between BSC and Banks' Performance

\begin{tabular}{|l|l|l|l|l|l|l|}
\hline Model & R & Rsquare & Adjusted R square & Std. Error of Estimate & ANOVA F-value & Sig \\
\hline 1 & $.773^{\mathrm{a}}$ & .598 & .559 & 15.148 & 15.618 & 0.000 \\
\hline
\end{tabular}

a. Predictors: (Constant), Learning and Growth Perspective, Customer Perspective Internal Business Process Perspective, Financial Perspective

b. Dependent Variable: Bank Performance

\section{Source: SPSS Computation}

Table 1 shows results of regressing the four perspectives of the BSC namely, financial perspective, customer perspective, internal business process perspective; and learning and growth perspective amongst banks' performance in Nigeria. The $\mathrm{R}^{2}$ of 0.598 shows the relationship between dependent and independent variables. The adjusted $\mathrm{R}^{2}=0.559$ (or $55.9 \%$ ) indicates that the four independent variables together explained $55.9 \%$ of variation that exist in the dependent variable. The remaining $44.1 \%$ could be attributed to exogenous variables that are not included in the model. The F-value (15.618) is significant at 0.05 level with its $\mathrm{P}$ value $=0.000$. This indicates a good predictive power.

Table 2:Results of regression analysis between BSC and Deposit Money Ban's' performance

\begin{tabular}{|c|c|c|c|c|c|c|}
\hline Model & & $\begin{array}{l}\text { Unstandardized } \\
\text { Coefficients } \\
\text { B }\end{array}$ & Std Error & $\begin{array}{l}\text { Standardized } \\
\text { Coefficients } \\
\text { Beta } \\
\end{array}$ & $\mathrm{T}$ & Sig. \\
\hline \multirow{5}{*}{1} & (Constant) & 117.393 & 18.706 & & 6.462 & .000 \\
\hline & Financial Perspective & .017 & .047 & .014 & 0.2979 & .908 \\
\hline & Customer perspective & .231 & .176 & .503 & 2.8580 & .003 \\
\hline & Internal Business & .411 & .136 & .293 & 2.1544 & .018 \\
\hline & $\begin{array}{l}\text { Process Perspective } \\
\text { Learning and Growth } \\
\text { Perspective }\end{array}$ & .316 & .174 & .321 & 1.8448 & .273 \\
\hline
\end{tabular}

a. Dependent Variable: BANK PERFORMANCE

Source: Computed from SPSS

From table 2, it can be observed that the customer perspective (Beta $=0.503, \mathrm{t}=2.8580, \mathrm{P}<0.05)$ and internal business process perspective (Beta $=0.293, \mathrm{t}=2.1544, \mathrm{P}<0.05$ ) have significant effect on the performance of banks in Nigeria. However, financial perspective (Beta $=0.014, \mathrm{t}=0.2979, \mathrm{P}>0.05)$ and learning and growth 
perspective (Beta $=0.321, \mathrm{t}=1.8448, \mathrm{P}>0.05$ ) have no significant effect on the performance of banks studied.

\subsection{Hypothesis One}

Financial perspective has no significant influence on business performance of selected banks in Nigeria.

From table 2, it is concluded that financial perspective has no significant influence on banks' performance in Nigeria, where (Beta $=0.014, \mathrm{t}=0.2979, \mathrm{P}>0.05$ ). The hypothesis that financial perspective has no significant influence on business performance of selected banks in Nigeria is accepted. The implication of this finding is that financial perspective does not signifncalty influence performance of banks in Nigeria.

\subsection{Hypothesis Two}

Customer perspective has no significant effect on the business performance of selected banks in Nigeria.

From table 2, it is concluded that customer perspective has a significant effect of banks' performance in Nigeria, where (Beta $=0.503, t=2.8580, \mathrm{P}<0.05$ ). the hypothesis that customer perspective has no significant effect on the business performance of selected banks in Nigeria is rejected. This implies that customer perspective is statistically significant and therefore impacts positively on performance of banks in Nigeria.

\subsection{Hypothesis Three}

Internal business process has no significant impact on the business performance of selected banks in Nigeria. From table 2, it is inferred that internal business process perspective has a significant impact on banks' performance in Nigeria, where (Beta $=0.293, t=2.1554, \mathrm{P}<0.05$ ). The hypothesis that internal business process has no significant impact on the business performance of selected banks' in Nigeria is rejected. The implication of this is that internal business process perspective contributes significantly to banks' performance in Nigeria.

\subsection{Hypothesis Four}

Learning and growth perspective has no significant effect on the business performance of selected banks in Nigeria. Table 2 indicates that learning and growth perspective has no significant effect on banks' performance in Nigeria where (Beta $=0.321, t=1.8448, \mathrm{P}>0.05)$. The hypothesis that learning and growth perspective has no significant effect on the business performance of selected banks in Nigeria is accepted. This implies that learning and growth perspectives effect on banks' performance in Nigeria is not significant.

\subsection{Discussion of Findings}

The findings of this study indicate that two independent variables namely customer perspective and internal business process perspective has significant effect and influence on the dependent variable, banks' performance in Nigeria. Findings also indicate that financial perspective and learning and growth perspective do not have a significant effect on banks' performance in Nigeria.

The financial perspective had a Beta value of 0.014 and $t$ value of 0.2979 which implies that financial perspective has no significant influence on sampled banks' performance. The finding contradicts Al-Mawali, Zainuddin and Ali (2010) whose findings indicated a significant relationship between financial perspective and performance of banking organizations. It also negates Panicker and Seshadri (2013) whose study established that financial performance was interwoven with other aspects of performance that combine to produce organizational performance.

In financial perspective, growth in revenue, growth rate and loan deposit ratio were used as proxies. This finding indicates that banks' performance in Nigeria is not significantly affected by its financial dimension. Hence decision on banks' performance should not be entirely based on financial performance.

The customer perspective had a Beta value of 0.503 and $t$ value of 2.8580 . This implies that customer perspective has a significant effect on the performance of sampled banks in Nigeria. It indicates that a unit improvement in customer related aspect of banks' operations, will lead to 0.601 improvement in banks' performance. The finding corroborates Rostami, Gourdarzi and Zaj (2015) whose study revealed customer perspective as having an important influence on banking institutions' performance. The study is also in tandem with Okoye, Odun and Odun (2017) whose related study indicated that customer perspective had a significant influence on the performance of manufacturing firms.

In the customer perspective, customer complaints redressed, customer retention rate and bank market share were used as proxies. In order to remain in business and also achieve their financial goals, banks need customers. The ability of bank to enjoy the patronage and loyalty of customers depends on customers experience such as prompt resolution of their relationship issues, empathy in attending to their needs and the banks' ability to deliver on their promises and the likes. This translates to sustained profitability for the banks. Hence, customers' perception of how their banking institutions are performing influences the latter to remain with these institutions or switch to other banks hoping to enjoy superior and more rewarding banking experience.

Internal business process perspective had Beta value of 0.293 and $t$ value of 2.1544. This implies a significant 
effect of internal business process perspective on banks' performance. The implication of this finding is that as banks improve their internal business process (such as e-banking, credit quality and cost efficiency which served as metrics internal business process perspective) by a unit, their overall performance improves by 0.281 . This outcome strengthens the earlier results of scholars such as Okoye, Odun and Odun (2017) whose findings established a significant effect of internal business process on the performance of manufacturing companies and Teker, Teker and Kent (2011) whose study indicated that non-financial indicator such as internal business process had become more important in measuring the performance of any firm in recent times. Thus, the ability of banking institutions to provide service to their customers promptly is to an extent related to how process - efficient these institutions are. A banking institution that manages its operation costs well will translate this to reduced cost of service enjoyed by customers. Further, banks that deploy current technology such as alternate channels to banking shorten time in service delivery as well as widen its service delivery reach. Also, with improved credit quality, more business and more income will come the way of the institution. The result will be better financial performance.

Learning and growth perspective had a Beta value of 0.321 and a t value of 1.8448 . The outcome implies that learning and growth perspective has no significant effect on banks performance in Nigeria. A further implication of this finding is that banks in Nigeria may not be giving much consideration to learning and growth aspect of their business (In terms of workforce diversity, growth in number of employees and profit per employee). This finding strengthens earlier finding by Okoye, Odun and Odun (2017) whose study reported an insignificant effect of learning and growth perspective on the performance of manufacturing firms, an indication that this perspective does not significantly influence manufacturing firms' performance. This finding however, negates earlier findings of Odera, Ombuna, Omido, Garashi and Okaka (2012) whose study revealed a relationship between learning and growth perspective and bank performance and Panicker and Seshadri (2013) whose related research showed a relationship between learning and growth perspective and banking institutions' performance.

Workforce diversity rate, growth in number of employees and profit per employee served as measures for learning and growth perspective. They are major indicators of learning and growth in organizations. Diversity rate of organizational workforce for instance, indicates how diverse and inclusive an organization is in terms of its employment policies and practices. In today's highly competitive business environment, an organization that is diverse and inclusive in its approach to employment has the opportunity to employ the brightest and creative staff irrespective of gender (IMF, 2015).Also, the growth in number of employees shows how the organization grows its work force yearly in relation to its age and volume of business. By growing its staff strength, the work load of existing staff would be reduced. This will facilitate employees' ability to deliver on the assigned duties with ease. Furthermore, profitability per employee measures institutions' profitability per staff. It is an indication of how productive the employees are in contributing to the institutions' ability to achieve their set goals. An organization that pays adequate attention to its learning and growth issues gains from improved employee and organizational performance.

\subsection{Conclusion}

Banks and other corporates are traditionally known to focus on financial perspective while neglecting the nonfinancial perspective which should complement and make the evaluation comprehensive and balanced for executive decision- making. This portrays a picture of no link between these two aspects of performance. Modernday reality in the business environment characterized by high and increasing level of competition, changing customers' tastes and general stakeholders' expectations requires a paradigm shift - balancing both financial and non-financial aspects of business performance. This approach will enable executive decision-making to be longterm in orientation. Such orientation enables an organization to effectively address different interests and expectations of customers, shareholders, employees and the like and so facilitate the organization's capacity in achieving long-term value creation.

The result of the study has validated the strength of BSC in facilitating an integrated assessment of the performance of banks in Nigeria for the period of 2007-2017 along different stakeholder dimensions. The findings of the study have given insights into how banks performed in different aspects of their operations in the period under review. The result has revealed that customer perspective and internal business process perspective have significant effect on banks' performance in Nigeria while financial perspective and learning and growth perspective do not have a significant influence on banks' performance. The study has proved that relying on financial indicators alone on bank performance evaluation is not enough. Hence, the need for an approach that captures performance from several perspectives.

\subsection{Recommendations}

Based on the findings, the following recommendations are made:

i. Banks in Nigeria should adopt the balanced scorecard model in reporting and managing their performance. This approach will provide additional information on their performance based on various dimensions.

ii. The significance of customer perspective on banks' performance in Nigeria signals banks should strategize 
more on customer related issues in order to win more business, improve and sustain their performance.

iii. The internal business process perspective holds a lot of potential for bank's profitability. Banks should invest more in this aspect of their operation through deployment of relevant technology and infrastructure, management efficiency and sound credit management in order to post superior performance.

iv. The performance of selected banks in the learning and growth perspective suggest the need for banks to address employee related issues of workforce diversity, growth in number of employees and staff productivity.

\subsection{References}

Abram, G. (1951). Risk Reduction as a Managerial Motive for Conglomerate Mergers. Bell Journal of Economics $12(2), 12-36$.

Akpan, E.J. (2013). Maximizing Equity Ownership and Corporate Value. Journal of Financial of Management 4(2) 11-20.

Al-Mawali, H., Zainuddin, Y. and Ali, N. (2010). Balanced Scorecard Usage and Financial Performance of Branches in Jordanian Banking Industry. International Journal of Social, Behavioural, Educational, Economic, Business and Industrial Engineering. 4(6) 33-39.

Atkinson, A. A., Kaplan, R. S., Matsumura, E. M., and Young, S. M. (2009). Management Accounting. Pearson Education: London

Collins, G.T. and Greg, B.Y. (2016). Performance and Profit Measures: The Formula for Firm's Survival. International Journal of Strategic Studies. 4(11), 212-219.

Edward, M.K. (2016). Towards a Balanced Reporting of Firms Performance. International Journal, Applied Management and Business 8(6) 94-106.

International Monetary Fund (2015).Diversity and Inclusion Annual Report

Kairu, E.W, Wafula, M.O., Okaka, O., Odera, O. and Akerele, E.K. (2013). Effects of Balance Scorecard on Performance of Firms in the Service Sector. European Journal of Business Management. (9) 81-88.

Kaplan, R.S. (2010). Conceptual Foundations of the Balanced Scorecard. Harvard Business School Working Paper 10-074.

Kaplan, R.S. and Norton, D.P. (1992). The Balanced Scorecard: Measures that Drive Performance. Harvard Business Review. 70(1) 71-79.

Kaplan, R.S. and Norton, D.P. (1996). Balanced Scorecard: Translating Strategy into Action. Harvard Business Review. 74(1) 75-85.

Kaplan, R.S. and Norton, D.P. (2001). TheStrategy-Focused Organization: How Balanced Scorecard Companies Thrive in the New Environment. Boston: Harvard Business School Press. P.296.

Kassahun, T. (2010). Rethinking Institutional Excellence in Ethiopia: Adapting and Adopting the Balance Scorecard (B.Sc) Model JBAS 2(1) 22-53.

Levit, U.U. (2016). Management. Ibadan: Granson Blue Diamond Press.

Malcom, S.E. (2016). Management and Organization Theory, Lagos, Nigeria: Philson Davis Publishing Limited. Mullins, L.J. (2014). Management and Organizational Behaviour. $5^{\text {th }}$ Edition, Essex, England: Prentice Hall.

Odera, O., Ombuna, D., Omido, K., Garashi, H. and Okaka, O. (2013). Impact of Balanced Scorecard Usage on the Performance of Commercial Banks. Irrational Journal of Information Technology and Business Management. 10(1) 40-48.

Okoye, E., Odun, A., and Odu, C. (2017). Effect of Balance Scorecard on Firm Value: The Case of Quoted Manufacturing Companies in Nigeria. In N. Madichie, A. Nkamnebe and G, Esu (eds.) African Entrepreneurship and Sustainable Development: Proceedings of International Conference, Faculty of Management Sciences, Nnamdi Azikiwe University, Awka, Nigeria. Pp 41-46. Awka: Scoa Heritage Nigeria.

Okwo, I.M. and Marire, I.M. (2012). Performance Measurement in Business Organizations: An Empirical Analysis of the Financial Performance of Some Breweries in Nigeria. Research Journal of Finance and Accounting. 3(11) 48-57.

Panicker, S. and Seshadri, V. (2013). Devising a Balanced Scorecard to Determine Standard Chartered Bank's Performance: A Case Study. International Journal of Business Research and Development 2(2) 35-42.

Rostami, M., Goudarzi, M. and Zaj, M. (2015). Defining Balanced Scorecard Aspects in Banking Industry using FAHP Approach. In national Journal of Economics and Business Administration, 1(1) 25-38.

Taker, S. and Aspinwall, E. (2010). Measuring Commercial Bank's Performances in Turkey: A Proposed Model. Journal of Applied Finance and Banking 1(3) 97-112.

Wong, Kee-Luen, Kuek Thiam-Yong and ONg Seng-Fook (2013). Strategic Planning and Business Performance: A Study of SMEs in Malaysia. Asia Pacific Business Research Conference Proceedings 25-16. Kuala Lumpur, p. 416.

Zeithaml, V. and Bitner, M. (2003). Service Marketing: Integrating Customer Focus across the Firm. McGrawHill, New York. P. 543. 